\section{FORTHCOMING EVENTS}

(Meetings marked with an asterisk are open to the public)

Monday, February 3

CNIVFrsity of LONDON (in the Physics Theatre, University College, Gower Street, London, W.C.1), at 5.30 p.m.- Prof. H. Alfven (Royal Cosmos".*

ROYAL SocIfTy of ARts (at John Adam Street, Adelphi, London, W.C.2), at 6 p.m.-Prof. A. Nove: "Soviet Russia To-day-Agrieulture". (Second of four Cantor Lectures.)

Sociftry of Chemical Industry, LONDON SECTION (at 14 Belgrave gress in Radioactive C.1), at 6.30 p.m.-Dr. W. P. Grove: "Recent Pro(

INSTITUTION OF ENGINEERING INSPECrION; the MATERIALS AND TESTING GROUP of the INSTITUTE OF PHYSICS AND THE PHYSICAL SOCIETY; the SOCIETY FOR NON-DESTRUCTIVE EXAMINATION; and the NON-DESTRUCTIVE 1 Birdcage Walk we BRITAIN (at the Institution of Mechanical Engineers, 1 Birdcage Walk, Westminster, London, S.W.1), at 7.15 p.m.-Dr. R. S.
Barnes: "The Relation between the Structure and Properties of Crystaline
Materials".

\section{Tuesday, February 4}

UNIVERSITY of LONDON (in the Anatomy Theatre, University College,
gower Street, London, W C.1) at Gower Street, London, W.C.1), at 1.15 p.m.--Dr. H. Kalmus: "Animals UNIVERSITY of LONDON (at the London School of Hygiene and Tropical Medicine, Keppel Street, Gower Street, Jondon, W.C.1), at 5.30 p.m.Diseases". (Eight of twelve lectures on "The Scientific the Demyelinating organized by the British Postgraduate Medical Federation.)*

UNIVERsity of LONDON (in the Physics Theatre, University College, Gower Street, London, W.C.1), at 5.30 p.m.- Prof. H. Alfvén (Royal nstitute of Tochnology, Stockholm): "Origin of the Solar System".*

UNIVERSITY OF LONDON (at the Institute of Archæology, 31-34 Gordon "Equare, London, W.C.1), at 5.45 p.m.-Mr. James Mellaart (Istanbul): INSTITUTION OF MECHANICAL ENGINERR, APPLIED MFChanicg AND STEAM PLANT GROUPS (at 1 Birdcage Walk, Westminster, London, S.W.1), to Pressures of about 1 Ton/In. ${ }^{2}$ and High Temperatures".

Plastics Institute (at the Wellcome Building, Euston Road, London, N.W.1), at 6.30 p.m.-Dr. W. B. Browu: "Polystyrene Foams".

\section{Wednesday, February 5}

ROYAL SOCIETY OF MEDICINE, HISTORY OF MEDICINE SECTION (at 1 UNIVERsity of LoNDON (at Bedford College, Inner Circle, Regent's Park, London, N.W.1), at 5.15 p.m.-Prof. C. Cherry: "The Scientific

Institute of PeTroleum (at 61 New Cavendish Street, London, W.1), at 5.30 p.m.-Mr. R. J. Russell and Mr. E. D. Chapman: "The Pumping
of $85^{\circ} \mathrm{F}$. Pour Point Assam (Nahorkatiya) Crude Oil at $65^{\circ} \mathrm{F}^{\circ}$.

BRITISH INSTITUTION OF RADIo ENGINEERS (joint meeting of the ComPUTHR and RADAR GROUPs, at the London School of Hygiene and Tropical Medicinc, Keppel Street, Gower Street, London, W.C.1), at 6 p.m.-Mr.

Institution of Mechanical Engineers, adtomatic Contror and HYDRADLIC PLANT
minster, London, S.W.1), at 6 p.m.-Mr. D. MeCloy and Mr. H. R. Martin: "Some Effects of Cavitation and Flow Sources in the Electrohydraulic Servomechanism".

UNIvensity of LondoN (at Birkbeck College, Malct Street, London, W.C.1), at 6 p.m.-Prof. G. Miller: "Psychological Studies of Language. II: Experiments with Syntax"."

SOCIETY OF ChEMICAL INDUSTRY, Food GROUP-Nutrition PANEL (at 14 Belgrave Square, London, S.W.1), at 6.15 p.m.-Mr. J. C. MeKenzic: .

ROYAL INSTITUTE OF CHEMISTRY, LONDON SECTION (joint meeting with the CIIELSEA COLLEGE OF SCIENCE and TFCHNOLOGY CHEMICAL SOCIETY, at the Chelsea Collego of Seience and Technology, Manresa Road, London,
S.W.3, at 7 p.m.-Dr. G. H. Williams: "Some Aspects of the Chemistry of Free Radicals",

\section{Thursday, February 6}

ROYAL SOcrery (at Burlington House, Piccadilly, London, W.1), at Study of the Crystal Structure of Benzine with a Neutron Beam"; Mr. A, R. Lang and Mr. M. Takagi: "X-ray Bragg Reflexion, 'Spike' Reflexion and Ultra-violet Absorption Topography of Diamonds".

UNIVERSITY of LONDON (at the London School of Hygiene and Tropical Medicine, Keppel Street, Gower Street, London, W.C.1), at 5.30 p.m.-
Prof. R. R. Porter: "The Structure of Antibodies". (Ninth of tweive Prof. R. R. "Porter: "The Structure of Antibodies". (Ninth of twelve Postgraduate Medical Federation.)*

INSTITUTE OF REFrigeration (at the National College for Hcating, Ventilating, Refrigeration and Fan Engineering, Southwark Bridge Road, London, S.E.1), at 6 p.m.-Mr. P. D. Laing and Mr. E. J. Perry: "

INSTITUTION OF MEChanical ENGINERRS, AUtomatic CONTROL Group (at 1 Birdcage Walk, Westminster, London, S.W.1), at 6 p.m.-Discussion

ROYAL SOCIETY OF MEDicine, NEUROLOGY SECTION (at 1 Wimpole Street, London, W.1), at 8 p.m.-Meeting on "Vaccination Against Polio-
myelitis".
Friday, February 7

ROYAL INSTITUTION (at 21 Albemarle Street, London, W.1), at 9 p.m.-
r. K. Mellanby: "Pesticides and Wild Life".

\section{Saturday, February 8}

LONDON COUNTY COUNCI (at the Horniman Museum, Iondon Road, "Torest Hill, London, S.E.23), at 3.30 p.m.-Mr. David R. MacGregor

\section{Monday, February 10}

Institution OF MEchaNical ENGINEERS, HYDraUlic PLANT AND MACHINERY GRoUP (at 1 Birdcage Walk, Westminster, London, S.W.1), at 6 p.m.-Discussion Meeting on "Net Positive Suction Head"-Do We

ROYal Geographical SOCIETY (at 1 Kensington Gore, London, S.W.7), 6 p.m.-Mme. Th. Ullens de Schooten: "Caspian Sketehes".

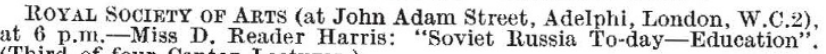
Third of four Cantor Lectures.)

INSTITUTION OF ELECTRICAL ENGINEERS, IONDON GRADUATE AND J. D. Iligham: "An A.C. Line Regulator Using Silicon Controlled Rectiliers",

\section{APPOINTMENTS VACANT}

APPLICATrons are invited for the following appointments on or before the dates mentioned:

SENIOR LECTURER IN PHYSICS-The Principal, College of Technology, Victoria Circus, Southend-on-Sea, Essex (February 6).

ASSISTANT IN LOGIC (General Philosophy or Formal Logic)-The Secretary of University Court, The University, Glasgow (February 7).

ASSISTANT LECTURER IN APPLIED MATHEMATICS-The Secretary, The Queen's University, Belfast, Northern Ircland (February 7)

CHIEF TECHNICIAN (with Higher National Certificate, City and Guilds Laboratory 'Technicians' Advanced Certificate or equivalent qualification, organization and administration) IN THE PHYSICS DEPARTMENT-Head, Physics Department, The University, Hull (February 7).

LECTURER/ASSISTANT LECTURER (qualified in pure mathematics) IN ATHEMATICS - The Registrar, The University, Keele, Staffs (February 7) INSTITUTE OF EDUCATION-The Registrar, The University, Liverpool, quoting Ref. CV/11 (February 10).

STAFF TUTOR IN PSYCHOLOGY in the Department of Adult Education and Extra-Mural Studies-The Registrar, The University, Liverpool, quoting Ref. CV/10 (February 10).

LECTURFR (with a degree in physiology, pharmacology or medicine, and postgraduate research experience of Yh.D. or equivalent standard) IN PHYSIOLOGY IN THE DEPARTMENT OF PHYSIOLOGY AND BIOCHEMISTRYThe Secretary and Registrar, The University, Southampton (February 14). TURNER AND NEWALL R RSEARCH FEILOWS IN ENGINEERING, INORGANid
CHEMISTRY, PHYSICS and allied subjects--The Registrar, The University, Manchester 13 (February 14).

UNIVERSITY DEMTONSTRaTOR IN VEThRINARY PARASITOLOGY-Dr. D. T. Kellaway, Department of Pathology, The University, Tennis Court Road, Cambridge (February 14).

VETRKINARY OFFICERS (men and women, aged at least 23, M.R.C.V.S. with at least one year's practical postgraduate experience) with the Ministry of Agriculture, Fisheries and Food, for posts in various parts of the country Ref. 130/64 (February 14).

ASSISTANT LECTURER or LECTURER IN STATISTICS-The Registrar, The University, Sheffield (February 15)

LECTURH IN DEVELOPMENTAL and EudCational Psychology-The Stanmer House, Stanmer, Brighton, Sussex

LECTURER Or ASSISTANT LECTURER (preferably with interests in the ENGINERRING-The Secretary and Registrar, The University, Southampton (February 15).

SENIOR LECTURER or LECTURFR IN OChaNOGRAPHY (Biological or Physical) IN THE OCEANOGRAPHIC RESEARCH INSTITUTE AND DEPARTMENT OF OCEANOGRAPHY, University of Natal-The Secretary, Association of Commonwealth (South Africa and London, February 15).

LECTURERS or ASSISTANT LECTURERS (with qualifications in either pure or applicd mathematics) IN MATHEMATICS-The Registrar (Room 22, O.R.B.) The University, Reading (February 17).

LECTURER (with qualifications in biochemistry or agricultural chemistry and a special interest in the field of animal nutrition) IN AGRICULTURA CHEMISTRY IN THE DFPARTMENT OF AGRICULTURAL SCIENCES-The Registrar, The University, Nottingham (February 19)

ASSISTANT LECTURER IN MATHEMATIOs, and an AsSistant LFCTURER or LECTURER IN MATHEMATICS-The Secretary, Westfield College (University

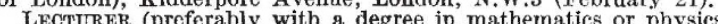

interest in the anplicentions of interest in the applications of mathematical techniques and compute interest in the physico-chemical aspects of chemice in chemistry and an interest in the physico-chemical aspects of chemical ongincering) within sity, Newcastle upon Tyne 2 (February 22).

Sity, Newcastle upon Tyne 2 (February 22 ). tion) IN THE DEPARTMENT OF SOCIAL SCIENCE-The Registrar, The University, Liverpool, quoting Ref. CV/21 (February 22).

stratioraphy or sedimentology) IN THE DEPAR in palæontology and Registrar, The University, Leeds 2 (February 24).

LECTURER (with special qualifleations and interests in cconomic geography) IN G EOGRAPHY-The Secretary, The Queen's University, Belfast, Northern Ireland (February 26).

ASSISTANT LECTURER (with an honours degree in engineering or science with metallurgy as a major subject, and preferably previous rescarch and/or teaching experience) IN PHYSICAL METALLCRGY - The Registrar, University of Melbourne, Parkville, N.2, Victoria, Australia, or The Secretary, House, Pall Mall, London, S.W.1 (Australia, February 28). 